\title{
A meditation on medications, among other things
} OPEN

Richard M. Ransohoff, $\mathrm{MD}$

Correspondence to Dr. Ransohoff: rransohoff@gmail.com

Neurol Neuroimmunol Neuroinflammation 2014;1:e37; doi: 10.1212/ NXI.0000000000000037
This third issue of Neurology ${ }^{\circledR}$ Neuroimmunology \& Neuroinflammation incorporates a number of fascinating and informative clinical reports, including a presentation of prion disease as hyperacusis from Merkler et al. ${ }^{1}$ as well as a case of NMDA receptor antibody disease associated with bilateral sensorineural hearing loss from Taraschenko et al. ${ }^{2}$ In the case reported by Merkler et al., central auditory processing is the suspected pathophysiology, while the data from Taraschenko et al. suggest that the cochlear apparatus was directly targeted by pathogenic autoantibodies. Together the 2 cases illustrate how much neurophysiology can be gleaned from thoughtful study of these unusual patients. We also present a transient episode of autoimmune autonomic ganglionopathy (AAG) from Baker et al. ${ }^{3}$ This case illustrates the clinical and scientific importance of case reports. Individuals with AAG harbor autoantibodies to ganglionic acetylcholine receptors, producing (usually) modest autonomic insufficiency syndromes. This case of transient symptoms in a neonate born to a patient with AAG confirms that the antibodies are directly pathogenic and also alerts clinicians to the potential for this complication of the disorder. FernándezFournier et al. ${ }^{4}$ report a careful study of cervical myelitis in a young girl, with onset only 3 days after human papillomavirus immunization. The extremely short interval between immunization and neuroinflammation, along with the presence of CSF oligoclonal immunoglobulin $\mathrm{M}$, are consistent with the possibility that a preexisting autoimmune diathesis was present. This challenges the research community to identify markers of the few individuals (insufficient numbers to exceed background in surveys) who may be at risk for expressing inflammatory complications of prophylactic immunization.

Another clinical study, from Morgello et al., ${ }^{5}$ addresses the complex relationships between vascular disease and chronic viral infection (in this case HIV with or without hepatitis $\mathrm{C}$ virus [HCV]). It has been clear for some time that HIV infection carries a risk of vascular disease, possibly related to a persistent inflammatory reaction. In this incisive study, Morgello et al. focus on small vessel cerebral disease and show that coinfection with $\mathrm{HCV}$ is an identifiable and substantial ( $20 \%$ of variance) risk factor. The methodology using multivariate analysis is hypothesis-raising rather than hypothesis-testing, but the findings will be of considerable public health and scientific utility.

Wang et al. ${ }^{6}$ describe a case of Lyme neuroborreliosis that is interesting because of its geography: this US patient manifested a syndrome of cranial polyneuritis and spinal radiculitis that would be familiar to non-US physicians but is quite atypical in the United States. The reasons for these differences are speculative (different Borrelia species? genetic or environmental host factors?), but the report will educate US physicians caring for such patients.

Two benchtop clinical research studies appear in this issue. In one, Williams et al. ${ }^{7}$ show that CCR2 chemokine receptor expression on a monocyte subpopulation often termed "intermediate" $\left(\mathrm{CD} 14^{+}\right.$/ $\mathrm{CD} 16^{+}$) may provide a suggestive indicator for cognitive impairment in HIV+ individuals. The findings integrate cognitive and laboratory investigation to yield data that may help to understand why some $\mathrm{HIV}+$ persons develop cognitive impairment as well as to identify those at increased risk. Thomas et al. ${ }^{8}$ also focus on a subset of mononuclear phagocytes, a newly described dendritic cell subset (termed "6-sulfo LacNAc+ dendritic cells" or "slan-DCs") whose $\mathrm{P}$ selectin glycoprotein ligand 1 is decorated with 6-sulfo N-acetyl-D-lactosamine rather than more common modifications. These cells have been proposed to drive pathogenic T-cell responses in other human conditions. Here the analysis is extended to include multiple sclerosis (MS) by examination of blood, CSF, and brain lesion cells. In addition, effects of several immunomodulatory MS treatments are examined. The data underline how little we securely know of the specific cellular interactions that produce neuroimmunologic diseases.

From the Neuroinflammation Research Center, Mellen Center for MS Treatment and Research; and Cleveland Clinic Lerner College of Medicine, Cleveland Clinic, Cleveland, $\mathrm{OH}$.

Go to Neurology.org/nn for full disclosures. Funding information and disclosures deemed relevant by the author, if any, are provided at the end of the editorial.

This is an open access article distributed under the terms of the Creative Commons Attribution-Noncommercial No Derivative 3.0 License, which permits downloading and sharing the work provided it is properly cited. The work cannot be changed in any way or used commercially. 
Finally, there are 4 articles illustrating the fascinating, complex human immunology implicit in the new treatment options available for MS and neuromyelitis optica (NMO), the prototypical neuroinflammatory conditions. Gelfand et al. ${ }^{9}$ provide a comprehensive case report, including autopsy findings, from an NMO case treated with alemtuzumab. An editorial discusses the implications of their findings. ${ }^{10}$ Kister et al. ${ }^{11}$ contribute the important observation that JC virus serologies (significant in their use for risk mitigation in candidates for treatment with natalizumab) are confounded by prior administration of IV immunoglobulin. Torkildsen et al. ${ }^{12}$ report that low-dose naltrexone, an alternative medication for MS without scientific or clinical evidence for efficacy, includes real risks with its uncertain benefits: in this instance, strongly suggestive indications that immune thrombocytopenic purpura was induced by the medication. Mehling et al. ${ }^{13}$ add to a highly useful series of investigations of the efficacy of immunization in those receiving immunomodulatory medication (in this case fingolimod) for MS. This clinically and scientifically valuable line of research needs to continue so that the treatment community understands fully how to use our new MS and NMO armamentarium. The cumulative effect of these reports emphasizes the exhilarating and challenging terrain in which we find ourselves during an era of therapeutics for inflammatory and immune disorders: the diseases are complex, the treatments are each typified by different mechanisms, and the potential complications (as well as benefits) are legion. Vigilance and vigorous research must be our watchwords.

\section{DISCLOSURE}

Richard M. Ransohoff conducts research supported by the NIH, the National MS Society, the DOD, the Alzheimer's Association, the Guthy-Jackson Foundation, Williams Family Foundation for MS Research, ChemoCentryx, Lundbeck, Teva, Novartis, Genzyme, and Biogen-Idec. Dr. Ransohoff has received fees for preclinical consulting or honoraria for academic presentations from Amgen, Genentech, Roche, Novartis, Biogen-Idec, and Pfizer. He serves on scientific advisory, medical advisory, or safety monitoring boards for ChemoCentryx and Vertex. He receives an honorarium from the AAN as the Editor of Neurology: Neuroimmunology \& Neuroinflammation. Go to Neurology.org/nn for full disclosures.

\section{REFERENCES}

1. Merkler AE, Prasad M, Lavi E, Safdieh J. Hyperacusis as the initial presentation of Creutzfeldt-Jakob disease. Neurol Neuroimmunol Neuroinflamm 2014;1:e32; doi: 10. 1212/NXI.0000000000000032.
2. Taraschenko O, Zimmerman EA, Bunch ME, McKee MA. Anti-NMDA receptor encephalitis associated with atrial fibrillation and hearing loss. Neurol Neuroimmunol Neuroinflamm 2014;1:e24; doi: 10.1212/NXI. 0000000000000024 .

3. Baker SK, Chow BM, Vernino SA. Transient neonatal autoimmune autonomic ganglionopathy. Neurol Neuroimmunol Neuroinflamm 2014;1:e35; doi: 10.1212/NXI. 0000000000000035.

4. Fernández-Fournier M, Díaz de Terán J, Tallón Barranco A, Puertas I. Early cervical myelitis after human papilloma virus vaccination. Neurol Neuroimmunol Neuroinflamm 2014;1:e31; doi: 10.1212/NXI. 0000000000000031

5. Morgello S, Murray J, Van Der Elst S, Byrd D. HCV, but not HIV, is a risk factor for cerebral small vessel disease. Neurol Neuroimmunol Neuroinflamm 2014;1:e27; doi: 10.1212/NXI.0000000000000027.

6. Wang E, Shirvalkar PR, Maciel CB, Merkler AE, Safdieh J, Gupta A. American neuroborreliosis presenting as cranial polyneuritis and radiculoneuritis. Neurol Neuroimmunol Neuroinflamm 2014;1:e30; doi: 10.1212/NXI. 0000000000000030

7. Williams DW, Byrd D, Rubin LH, Anastos K, Morgello S, Berman JW. CCR2 on CD14+CD16+ monocytes is a biomarker of HIV-associated neurocognitive disorders. Neurol Neuroimmunol Neuroinflamm 2014;1:e36; doi: 10.1212/NXI.0000000000000036.

8. Thomas K, Dietze K, Wehner R, et al. Accumulation and therapeutic modulation of 6-sulfo LacNAc+ dendritic cells in multiple sclerosis. Neurol Neuroimmunol Neuroinflamm 2014;1:e33; doi: 10.1212/NXI. 0000000000000033.

9. Gelfand JM, Cotter J, Klingman J, Huang EJ, Cree BAC. Massive CNS monocytic infiltration at autopsy in an alemtuzumab-treated patient with NMO. Neurol Neuroimmunol Neuroinflamm 2014;1:e34; doi: 10.1212/NXI. 0000000000000034

10. Fujihara K, Nakashima I. Secondary progression and innate immunity in NMO: a possible link to alemtuzumab therapy? Neurol Neuroimmunol Neuroinflamm 2014;1: e38; doi: 10.1212/NXI.0000000000000038.

11. Kister I, Kuesters G, Chamot E, et al. IV immunoglobulin confounds JC virus antibody serostatus determination. Neurol Neuroimmunol Neuroinflamm 2014;1:e29; doi: 10.1212/NXI.0000000000000029.

12. Torkildsen $\varnothing$, Myhr K-M, Wergeland S. Treatmentresistant immune thrombocytopenic purpura associated with LDN use in a patient with MS. Neurol Neuroimmunol Neuroinflamm 2014;1:e25; doi: 10.1212/NXI. 0000000000000025.

13. Mehling M, Eichin D, Hafner P, Hönger G, Kappos L, Hess C. Avidity of vaccine-induced influenza IgG fails to increase in fingolimod-treated patients with MS. Neurol Neuroimmunol Neuroinflamm 2014;1:e28; doi: 10.1212/ NXI.0000000000000028. 


\section{Neurology \\ Neuroimmunology \& Neuroinflammation}

A meditation on medications, among other things

Richard M. Ransohoff

Neurol Neuroimmunol Neuroinflamm 2014;1;

DOI 10.1212/NXI.0000000000000037

This information is current as of October 30, 2014

\section{Updated Information \& Services}

References

Permissions \& Licensing

Reprints including high resolution figures, can be found at:

http://nn.neurology.org/content/1/3/e37.full.html

This article cites 13 articles, 0 of which you can access for free at: http://nn.neurology.org/content/1/3/e37.full.html\#\#ref-list-1

Information about reproducing this article in parts (figures,tables) or in its entirety can be found online at:

http://nn.neurology.org/misc/about.xhtml\#permissions

Information about ordering reprints can be found online: http://nn.neurology.org/misc/addir.xhtml\#reprintsus

Neurol Neuroimmunol Neuroinflamm is an official journal of the American Academy of Neurology.

Published since April 2014, it is an open-access, online-only, continuous publication journal. Copyright $@$ 2014 American Academy of Neurology. All rights reserved. Online ISSN: 2332-7812.

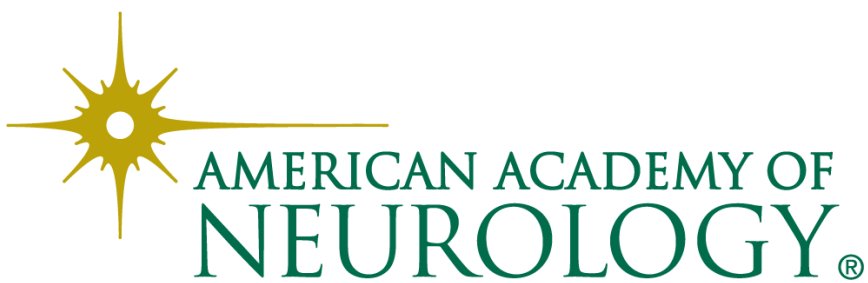

